Article

\title{
What Challenges Does the 21st Century Impose on the Knowledge of Primary School Teachers Who Teach Mathematics? An Analysis from a Latin American Perspective
}

\author{
Claudia Vásquez ${ }^{1, *(\mathbb{D})}$, Juan Luis Piñeiro ${ }^{2}$ and Israel García-Alonso ${ }^{3}$ (D) \\ 1 Campus Villarrica, Pontificia Universidad Católica de Chile, Villarrica 4930445, Chile \\ 2 Faculty of Philosophy and Education, Universidad Metropolitana de Ciencias de la Educación, \\ Santiago 7760197, Chile; juanluis.pineiro@umce.cl \\ 3 Department of Mathematical Analysis, University of La Laguna, 38206 San Cristóbal de La Laguna, Spain; \\ igarcial@ull.edu.es \\ * Correspondence: cavasque@uc.cl
}

Citation: Vásquez, C.; Piñeiro, J.L.; García-Alonso, I. What Challenges

Does the 21st Century Impose on the Knowledge of Primary School Teachers Who Teach Mathematics? An Analysis from a Latin American Perspective. Mathematics 2022, 10, 391. https://doi.org/10.3390/ math10030391

Academic Editors: Elena Castro Rodríguez, Ana Belén Montoro Medina and Valery Karachik

Received: 3 January 2022

Accepted: 26 January 2022

Published: 27 January 2022

Publisher's Note: MDPI stays neutral with regard to jurisdictional claims in published maps and institutional affiliations.

Copyright: (C) 2022 by the authors. Licensee MDPI, Basel, Switzerland. This article is an open access article distributed under the terms and conditions of the Creative Commons Attribution (CC BY) license (https:// creativecommons.org/licenses/by/ $4.0 /)$.

\begin{abstract}
Curricula are usually pointed out as one of the factors that delimit teacher's knowledge. In this context, this study analyzes the requirements for teacher's knowledge that can be found in the curricular guidelines of Mathematics Education in the three Latin American countries belonging to the OECD to educate in sustainability. For this, a content analysis has been carried out that examines the meaning given to the teaching and learning of mathematics that would allow the development of key sustainability competences. The results show a teaching-learning process of mathematics that is not very aligned with education for sustainable development, with a low presence of key competences for sustainability. These results represent a roadmap, both for teacher training institutions and for providing a new educational approach that allows Mathematical Education to contribute to educating in sustainability in Primary Education. This new approach should promote students' understanding of the different problems (social, economic, and environmental) that we are faced with, as well as the measures that must be adopted to transform and act towards a more sustainable world.
\end{abstract}

Keywords: education for sustainable development; sustainable development goals; sustainable development approach; teacher knowledge; primary mathematics curricula

\section{Introduction}

Currently, teachers are challenged to be agents of change in a world that is amid an unprecedented global, climate, health, environmental, and social crisis. This fact leads us to rethink the way of educating in the different disciplines and at all educational levels in order to change the way we relate to our environment and the world. Therefore, today more than ever it is necessary to have an education that contributes to raising awareness and allowing citizens to effectively face one of the most urgent challenges of the 21st century: sustainable development. It is in this direction that the United Nations Educational, Scientific and Cultural Organization (UNESCO) raises the need to promote Education for Sustainable Development (ESD) at all educational levels. This is undoubtedly a global challenge that implies promoting practical actions to build a better future together, to end poverty and inequalities, and to achieve peace and justice, to protect human rights and our planet [1]. Therefore, it is imperative that "all educational institutions -from preschool to higher education and formal, non-formal and informal education- foster the development of sustainability competences" [2] (p. 2). The latter is understood as a set of cognitive skills, practical knowledge, values, and attitudes that must be raised in situations that involve contexts related to sustainability [3].

However, how can we address this challenge in the primary mathematics classroom? It is certainly not an easy task, as it requires a new way of approaching mathematics 
teaching, focused on teaching in connection with sustainability. In this way, students would be allowed to achieve specific cognitive, socio-emotional, and behavioral learning linked to the Sustainable Development Goals (SDG), and especially, develop competences for sustainability [1]. A key element in this process is teachers, their knowledge and skills, as these "are powerful agents of change, who can provide the educational response necessary to achieve the SDGs. The competences possessed by a teacher are essential to restructure educational processes and institutions in pursuit of sustainability" [1] (p. 51). Therefore, Mathematics Education and, specifically, teacher training is fertile ground to help raise awareness, understand, reflect, and act on one of the most pressing challenges in today's world: Education for Sustainable Development. This is because it is crucial knowledge that every citizen can use to contribute to the development of a better society, economically as well as socially and environmentally [4].

\section{Study Rationale}

Addressing teacher training in line with ESD requires research on the knowledge that teachers need to acquire to be competent in teaching mathematics in connection with sustainability. This is based on the fact that the activities that teachers implement in the classroom depend a lot on their professional knowledge [5] and have a direct impact on their students' learning [6]. Although teacher knowledge is a relevant field of study in Mathematics Education [7], there is little evidence regarding the knowledge required by teachers who teach mathematics to promote teaching in connection with sustainability. For example, different models of mathematics teacher knowledge do not consider elements such as sustainability [8]. While this is because the different theoretical perspectives that describe teacher knowledge have a different purpose, their different dimensions are potentially a way to identify and incorporate ESD in mathematics classes. Therefore, this is a field of study that demands attention, especially if we consider that in some cases teachers may perceive themselves as incompetent to implement ESD in their classrooms in subjects such as mathematics [9]. This, based on the fact that "it is not only integrate contents such as climate change, poverty and sustainable consumption into the curriculum; it also creates interactive, learner-centred teaching and learning settings. What ESD requires is a shift from teaching to learning" [1] (p. 7).

Against this background, in this study, we focus on investigating the opportunities offered by Primary Education mathematics curricula and the demands they place on teachers' knowledge. For the first action of identifying what opportunities are provided by the mathematics curricula for Primary Education, we have selected the curriculum guidelines of Chile, Mexico, Costa Rica, and Colombia. The selection is made taking onto account that they are countries of the Latin American and Caribbean region that are members of the Organization for Economic Cooperation and Development (OECD), and therefore, adhere to the 2030 agenda for sustainable development [10]. On the other hand, these four developing countries are the only ones in the Latin American and Caribbean region that adhere to the 2030 agenda. Therefore, it is necessary to reflect on the goals of this agenda in order to support decision making and strengthen public policies in the region. In this way, it will be possible to have clear guidelines that will allow progress from the first educational levels towards the achievement of one of the great challenges for teachers in the 21st century, such as the 2030 agenda. From our perspective, clarity about curricular goals and their opportunity to develop key sustainable development competences would, in a second step, shed light on the challenges this poses to the knowledge required by teachers to promote ESD. This is important as it has been pointed out that curricula frame the teacher's knowledge [11]. In this sense, we understand that the curricula of different educational systems vary in detail and depth and are often are not even based on research. However, it is important to know what is required to implement them from the teacher's perspective, because ultimately, it is the teachers who implement this knowledge [12]. In addition, such analysis will shed light on a priority area of action for ESD by 2030: the development of teacher knowledge and competences to achieve the 17 SDGs [13]. 
Specifically, the development of key competences for sustainability in all disciplines and at all educational levels will contribute to the development of sustainability literacy, i.e., the development of "skills, attitudes, competencies, dispositions and values necessary to survive and thrive in the world's declining conditions in order to mitigate such decline as much as possible" [14] (p. 10). It should be clear that while these competencies are transversal, multifunctional, and independent, they need to be developed (at different levels according to age) by all learners worldwide and do not replace situation- and context-specific competences, but rather complement them and extend them $[15,16]$. This entails a different approach to 21st century education and imposes not only the need for sustainability-literate citizens, but also challenges teachers to be responsible for the education of tomorrow's citizens [17]. For this reason, it is necessary to provide teachers with training that enables them to develop the above competences in their students. They must also have the tools to transform their teaching practices, usually focused on memorization and repetition of concepts, procedures, and formulas, towards teaching that considers the design and implementation of learning experiences focused on sustainability. In this sense, this work provides two key elements: a) to make explicit the learning objectives present in the mathematics curricula for Primary Education that direct teaching towards the achievement of key competences in sustainability and b) to identify which aspects of the teacher's knowledge need to be complemented in order to implement a curriculum that has a focus on ESD.

\section{Mathematics Education, Teachers' Knowledge, and Education for Sustainable Development}

Teachers today face the challenge of carrying out teaching that allows us to respond to the challenges of the 21st century, especially in subjects such as mathematics, which in many cases are characterized by teaching centered on the resolution of decontextualized exercises [18]. This leads to a lowered mathematical competence. It is, therefore, necessary to provide students with tools that enable them to understand the role of mathematics in the world, in solving real problems from local and global contexts. In this sense, we understand mathematical competence as: "an individual's ability to identify and understand the role that mathematics plays in the world, to make informed judgements and to be able to use and engage with mathematics" [19] (p. 12). Approaching mathematics education from a learner-centered perspective will not only allow the development of this competence but will also provide the necessary scaffolding to form change-agents citizens with whom to achieve progress towards a sustainable world of sustainable, democratic lifestyles and well-being for all.

This scenario demands that teachers promote their professional competences and that these competences enable them to develop in their students what is expected by today's societies. In this context, teacher's professional knowledge becomes a central element in what is understood as the mathematics teacher competence [20]. Since the contribution by [21], multiple frameworks have emerged that have attempted to represent the mathematics teacher's knowledge. These models have been largely based on the work of [21] and have focused mainly on two domains of teachers' knowledge: content knowledge and didactic content knowledge. We highlight the work of Carrillo and collaborators [8], because unlike other frameworks mentioned, it makes explicit the knowledge of processes as fundamental as problem solving. These authors consider two major areas of knowledge in teachers: mathematical knowledge and didactic content knowledge, both of which are interwoven in the beliefs held by teachers. Each area has specific subdomains. As indicated by the previous authors, mathematical knowledge is understood:

As a network of systemic knowledge structured according to its own rules. Having a good understanding of this network-the nodes and connections between them-the rules and features pertaining to the process of creating mathematical knowledge enables the teacher to teach content in a connected fashion and to validate their own and their students' mathematical conjectures. [8] (p. 241) 
This domain is composed of three subdomains: the mathematical content itself (Knowledge of topics-KoT); the interconnection systems that link concepts (Knowledge of the structure of mathematics-KSM); and how mathematics progresses (Knowledge of practices in mathematics-KPM). Regarding didactic content knowledge, Carrillo and collaborators [8] pointed out that:

More than being about the intersection between mathematical and general pedagogical knowledge, it is a specific type of knowledge of pedagogy which derives chiefly from mathematics. Hence, we do not include in this sub-domain general pedagogical knowledge applied to mathematical contexts, but rather only that knowledge in which the mathematical content determines the teaching and learning which takes place (p. 246).

This has led to the identification of three subdomains that have been named knowledge of mathematics teaching (KMT), knowledge of features of learning mathematics (KFLM), and knowledge of mathematics learning standards (KMLS). It is, therefore, a useful theoretical construct as it allows the identification of knowledge related to mathematics teaching. However, these models are challenged in the face of ESD in the sense of what needs to be known and understood, what knowledge is involved in bringing the mathematics curriculum into the classroom while meeting sustainability demands.

Thus, in addition to developing knowledge linked to mathematics as a teaching object, today's societies advocate focusing teaching on the development of key competences for sustainability which, by their nature, involve problem-solving that addresses diverse issues, with the aim of "empowering and equipping present and future generations to meet their needs through a balanced and integrated approach to the economic, social and environmental dimensions of sustainable development" [22] (p. 7). While it is true that there is still no common framework in relation to sustainability competences [2], there is clarity about which competences teachers need to develop and implement in educational settings with their students in order to move towards a sustainable world. Thus, according to UNESCO [1] (p. 10), the following key competences for sustainability and the skills they include are considered:

1. Systems thinking competence: recognizing and understanding relationships; analyzing complex systems; thinking about how systems are integrated across domains and scales; and dealing with uncertainty.

2. Anticipatory competence: understanding and evaluating multiple future scenarios; creating one's own visions of the future; applying the precautionary principle; assessing the consequences of actions; and dealing with risks and changes.

3. Normative competence: understanding and reflecting on the norms and values that underlie our actions; and negotiating sustainability values, principles, objectives, and goals in a context of conflicting interests and trade-offs, uncertain knowledge, and contradictions.

4. Strategic competence: collectively develop and implement innovative actions that promote sustainability at the local level and beyond.

5. Collaborative competence: to learn from others; to understand and respect the needs, perspectives, and actions of others (empathy); to understand, identify with, and be sensitive to others (empathetic leadership); to deal with conflict in groups; and to facilitate collaborative and participatory problem solving.

6. Critical thinking competence: questioning norms, practices, and opinions; reflecting on one's own values, perceptions, and actions; and taking a stand in the sustainability discourse.

7. Self-awareness competence: reflecting on one's role in the local community and in (global) society; constantly assessing and driving one's own actions; and dealing with personal feelings and desires.

8. Integrated problem-solving competence: apply different problem-solving frameworks to complex sustainability problems and devise equitable solution options that promote sustainable development, integrating the above competences. 
ESD aims to develop sustainability-literate learners, i.e., "empowered to make conscious decisions and act responsibly for environmental integrity, economic viability and a fair society for present and future generations" [1] (p. 7). To achieve this, we must develop a teaching model that promotes the key competences for sustainability and the skills outlined above aimed at achieving a holistic and transformative education [1]. The choices that are made through the teaching process mean that at least four different perspectives of ESD can be developed, depending on the learning focus. These four perspectives or approaches are integrative, critical, transformative, and contextual [23].

We understand that the ESD developed has an integrative approach when it presents a holistic perspective that integrates various aspects of sustainability. This happens when teaching is directed at understanding the factors that promote sustainability from different perspectives, e.g., economic, environmental, and social. Not only the description but also the analysis of their interrelationship is carried out to understand the reasons that contribute to sustainability. The critical ESD approach focuses on critical thinking that questions the dominant paradigm, such as production-consumption or energy-welfare models, for example, and through awareness-raising promotes alternatives in line with the SDGs. The third approach, transformative, is close to the previous ones, but in this case, it has a more pragmatic view and seeks real transformation, responsibility, and empowerment to achieve changes in lifestyles, values, companies, etc. in order to achieve sustainability. Finally, the contextual approach focuses teaching on the implications of context for sustainability. There is no one-size-fits-all model of sustainability, and each place and each community may approach the development of the SDGs in a different way, adapted to the natural resources and needs it possesses. The contextual approach emphasizes what is available to us to promote sustainability competences.

As we have seen, the different approaches to ESD allow, in turn, that each place on the planet, each teacher, each education system, can approach ESD with a certain flexibility without losing sight of the fact that, together, combining all the approaches, we can achieve to have citizens who are competent in sustainability. This is a challenge for teachers, even more so if they are mathematics teachers, who tend to consider that their areas are more distant from sustainability proposals $[9,24,25]$.

These approaches seek to contribute to the development of key competences for sustainability in an integrated manner with the SDGs. Undoubtedly, designing and implementing learning experiences that incorporate such approaches represents a challenge that requires adopting disciplinary, interdisciplinary, and transdisciplinary teaching perspectives on sustainability issues, which converge in a trans-formative action-oriented pedagogy "that engages learners in participatory, systems, creative and innovative thinking and action processes in the context of local communities and students' everyday lives" [1] (p. 52). This poses a challenge for teachers and teacher educators, especially in the areas of physics, chemistry, and mathematics, as they may be less aware of their competences to implement ESD education [9,24,25], even more so if we consider that according to [26] there is great complexity in incorporating ESD into the educational practice. Thus, if we want to implement SDG learning through ESD, it requires joint and articulated work among the following five fields of action: (a) integrating ESD into educational policies, strategies and programs; (b) integrating ESD into curricula and textbooks; (c) integrating ESD into teacher education; (d) teaching ESD in the classroom and other learning settings; and (e) assessing ESD learning outcomes and the quality of ESD programs.

Thus, to advance in ESD, it is essential to make ESD-literate teachers so that they value and pay attention to its incorporation in the school context [27]; at the same time, we need to have the necessary tools to empower their students as citizens of sustainability [17], for while teachers value ESD, they have little clarity on how to design and implement teaching processes aimed at incorporating ESD in the school classroom [9]. The aim is for teachers to contribute to the transition to a sustainable society by being able to promote their students constructive and responsible participation in the world they live in. 


\section{Method}

To achieve the objective of identifying which aspects of the key competences are present in Primary School curricula and how they challenge the teacher's knowledge, we used a non-interactive qualitative approach in this study [28]. In addition, it is important to note the descriptive nature of the content analysis [29].

\subsection{Sample}

The selected sample is purposive and is composed by the official curriculum guidelines for Primary Education (grades 1-6) published by governmental organizations in the four OECD member countries of the Latin American and Caribbean region [30]: Mexico [31], Chile [32], Colombia [33,34], and Costa Rica [35]. It should be noted that in the case of the Colombian curriculum guides, two documents were used: the 2006 document to analyze the approaches present in the curriculum and the 2017 document to analyze the learning objectives and their relationship with the key competences. Another important aspect to mention is that the Costa Rican and Mexican documents incorporate some aspect of sustainability in a cross-cutting manner. However, neither incorporates it in their learning objectives. For example, the Costa Rican curriculum, in its methodology section, presents problems and various learning activities to show how to include aspects of the four cross-cutting themes (environmental culture for sustainable development, comprehensive sexuality education, health education, and the experience of human rights for democracy and peace).

However, given that our second task is to identify the requirements that curriculum documents make of teachers as broadly as possible, the sampling procedure was designed to obtain richness, depth, and quality of information through case-type sampling [28]. We understand that Latin American OECD countries meet a number of criteria that make their curriculum documents valuable sources of information. Consequently, our aim was not to analyze the curriculum documents comparatively, but to identify the knowledge needed to implement these guidelines.

\subsection{Analysis Units}

The procedure for selecting the units of analysis involved two approaches. The first involved two actions: (a) identifying the section of each document where the general aims of the subject for the Primary Education stage are set out; and (b) identifying the objectives that set out the learning outcome for each Primary Education level. For the former, two types of units of analysis were used together, syntactic and thematic, in order to improve reliability. We understand syntactic units from the viewpoint of [36], who described them as natural syntactic elements that are highly reliable due to their small size and thematic units to indicate correspondence with a particular structural definition of content. Thus, the units of analysis were phrases and sentences that explicitly refer to the terms that comprise the approaches to ESD and its key competences. About the identification of objectives, the contents proposed by the curriculum were established and organized according to the level to which they corresponded and the mathematical axis to which they alluded (Numbers and operations, Geometry, Measurement, Algebra, and Statistics and Probability).

Such analyses require a numbering rule to guide them. We apply the rule of presence [37], since presence/absence is significant for our aim of describing a specific type of knowledge in its totality.

\subsection{Analysis Procedure and Categories}

The analysis involved three actions: two performed simultaneously and with a deductive character, and a third action with an inductive type. Specifically, (a) we identified references of approaches to ESD in the mathematics subject descriptions in each curriculum document; (b) we identified references/allusions to key competences for sustainability in the learning objectives for grades 1-6; and (c) we analyzed what the curricula stated about 
approaches to ESD and key competences using content analysis. Therefore, data analysis combines concept-driven and data-driven development [38].

First, the analytical categories were established following the theoretical perspective of ESD, which we understand as approaches to ESD and key competences [1]. For ESD approaches, we used four categories: holistic, contextual, transformative, and critical. Regarding key competences for sustainability, we used eight categories: systems thinking, anticipation, normative, strategic, collaboration, critical thinking, self-awareness, and problem solving. This deductive process was used to establish the initial organization of the units of analysis.

For example, the following unit of analysis was found in the Chilean document [32]: "The formative purpose of this subject is to enrich the understanding of reality" (p. 86). This statement indicates an emphasis on a holistic perspective of the subject. Therefore, it proposes a mathematics education not only based on the transfer of content, but rather action, which lends itself to promote participation in practices that eventually, under proper direction by the teacher, incorporates sustainability. This specification led us to classify the statement as integrative approach. Related to the sustainability key competences, a similar process was carried out.

Additionally, in the case of approaches to ESD, we followed the initial analysis with inductive analysis, or analysis within each category, which enabled us to establish more specific patterns. For example, we found additional units of analysis not mentioned above, such as:

- It is also necessary to incorporate the political, social, and cultural purposes of mathematics education, which implies taking into consideration the current state of society, its trends of change, and the desired futures towards which the mathematics education project is oriented [33] (p. 48).

- What is sought is the development of greater capacities of the citizen to face the challenges of the world of which they are a part of [35] (p. 14).

In all these units of analysis, we observe references to mathematical competence as an ability to understand and act in various real contexts.

To verify the reliability of the coding and in order to validate the categorization system, the authors jointly analyzed the curriculum documents. In this way, the reliability of the coding was safeguarded through joint coding sessions and discussion of disagreements until agreement was reached. This allowed the data to be collected and recorded in an MS Excel $^{\circledR}$ spreadsheet for further analysis.

\section{Results}

The results section is organized in two sections corresponding to the analyses conducted: teaching approaches to ESD and key competences for sustainability.

\subsection{Teaching Approaches to ESD}

The analysis of the approaches that are present in the respective curricula shows that the approach that is most present in the different documents is the contextual one. On the other hand, the least present approach is the transformative one. Likewise, the results show that each curriculum guideline has a different focus. For example, the Colombian and Chilean documents focus on the contextual approach, while the Costa Rican and Mexican documents focus on the critical and contextual approaches. Table 1 shows the frequency of references to each approach per country.

\subsubsection{Integrative}

The integrative approach brings together allusions to the integrative nature of the subject and how this helps to understand the reality surrounding the person. The first group of extracts corresponds to those that point out that in school mathematics "mathematical competence is interpreted...as an ability to use mathematics to understand and act in various real contexts, underlines a relationship of this discipline with physical and socio- 
cultural environments and also gives a privileged place to problem posing and problem solving" [35] (p. 14). On the other hand, the extracts refer to how the subject promotes a type of thinking that relates various aspects of school education which encourage learning that allows students to act on the reality around them. An example of this is the fact that teaching mathematics in Primary Education "implies incorporating a vision of mathematics as a culturally mediated human activity that has an impact on the social, cultural and political life of citizens" [33] (p. 48).

Table 1. Frequency of references to ESD approaches in curriculum documents.

\begin{tabular}{ccccc}
\hline & Integrative & Critical & Transformative & Contextual \\
\hline Colombia & 7 & 8 & 7 & 20 \\
Chile & 2 & 8 & 9 & 21 \\
Costa Rica & 15 & 17 & 6 & 22 \\
Mexico & 8 & 26 & 4 & 24 \\
\hline
\end{tabular}

\subsubsection{Critical}

The analysis has found that the critical approach presents two patterns within the curricular documents. Specifically, it is pointed out that school mathematics is, by definition a path for the development of critical thinking through its different knowledge and practices (logical reasoning, argumentation, problem solving, etc.). For example, the Chilean document states that "learning mathematics is fundamental for the formation of critical and adaptable citizens; able to analyse, synthesize, interpret and face increasingly complex situations; willing to solve problems of various kinds" [32] (p. 86). Likewise, the documents show how this development of thought would allow to interact appropriately with the setting. Particularly, the Colombian document indicates that a new role of the subject is configured, explaining that "a new political function is added to the other functions of mathematics education: concern for the training in democratic values and the exercise of critical citizenship" [33] (p. 48).

\subsubsection{Transformative}

The different allusions made by the curriculum documents have shown two focuses referring to a transformative approach to ESD. The first one is related to the fact that school mathematics allows the development of thinking to transform the reality that surrounds students. The second focus is related to the fact that school mathematics allows a change and transformation of thought itself.

Concerning the first group of allusions, they are related to school mathematics as a tool for preparing students for the change and transformations demanded by today's societies. Specifically, fragments have been found regarding how mathematics education should provide students with competences that allow them to act for change or make decisions to change their reality. For example, one of the allusions indicates that "Mathematics Education provided in school classrooms must find its general meaning in the development of individuals' abilities to intervene in a better way in life" [35] (p. 13).

The second group of allusions revolves around the idea that school mathematics is a source for students to become human beings who seek new paths and solutions or to be flexible and adaptable to circumstances. For example, the Chilean document points out that problem solving in mathematics offers students the opportunity to face challenging tasks that require "knowledge that does not follow pre-established schemes" [32] (p. 87).

\subsubsection{Contextual}

The contextual approach is the majority in the four documents. Generally, the allusions refer to the need for school mathematics to relate to the students' everyday setting and to be able to act in it through problem solving to provide solutions to current problems. In particular, it is possible to identify three patterns. The first of these points out that mathematics education should be connected to everyday situations. For example, an 
excerpt states that in the subject "what is intended is the development of the citizen's greater capacities to face challenges of the world of which he or she is a part" [35] (p. 11). In the second group of responses, we find references that deal with problem solving. Specifically, we find allusions that indicate that the subject should encourage students to "have divergent thinking in order to find novel solutions to hitherto unknown problems" [34] (p. 296). Finally, the third group deals with fragments that make explicit the inseparable link that should exist between problem solving and students' everyday situations. In this pattern we find that the subject should "contextualize learning by means of real problems that relate mathematics to concrete situations, and thus facilitate meaningful learning of fundamental mathematical content" [32] (p. 86).

\subsection{Key Competences for Sustainability}

The analysis of the curriculum documents of the four countries shows that there is no explicit mention of key competences for sustainability. However, it should be borne in mind that these curriculum documents were not designed according to this logic. From this perspective, what can be identified are the learning objectives which, in their implementation, show the capacity to potentially promote the development of key competences for sustainability. For example, let us look at the following learning objective for the 5th grade of the Colombian curriculum: "Formulate questions that require comparing two groups of data, for which collect, organize, and use frequency tables, bar graphs, pie charts, line graphs, among others. Analyse the information presented and communicate the results" [34] (p. 42). Here, it is not possible to identify a key competence for sustainability explicitly. However, the process of a statistical research cycle necessarily involves developing learning collectively among students, either by developing the instruments or collecting, analyzing, or sharing the data with the community. Furthermore, this allows us to visualize that this process can be developed in local contexts focused on achieving sustainable solutions to real problems, thus contributing to the development of at least the following key competences: systems thinking, normative, strategic, collaborative, critical thinking, and problem solving.

From this position, from the coding and frequency of the analysis units, it is possible to identify different approach intensities to the different competences in the curriculum documents (Figure 1).

At a general level, problem solving is the one that is most approached, as most of the learning objectives are focused on applying mathematical concepts and/or properties to problem solving from everyday contexts or which emerge from mathematics. Such is the case of the following learning objective defined for Grade 3 of the Chilean curriculum: "Solve routine problems in everyday contexts, involving money and involving the four operations (not combined)" [32] (p. 108). As in the previous cases, a key competence for sustainability is not explicitly evident in this learning objective. However, such an objective is focused on problem solving, and contextualized in everyday settings linked to local issues involving the four basic operations and the use of money, it would be situated in the development of problem-solving competence; it could trigger an approach to problem solving, leading to home financial education, for example, as a context for educating students in sustainability.

On the other hand, Figure 1 shows that in the curricula of Colombia, Chile, and Mexico, there are no learning objectives that allow us to approach the competence of selfawareness. The Costa Rican curriculum, on the contrary, shows the potential to trigger the competence of self-awareness, specifically the learning objective proposed for Grade 6: "To use probabilities to favour decision-making" [35] (p. 261). Thus, this learning objective, by contextualizing the calculation of probabilities in real situations that address meaningful problems for students, can encourage, from the data used, reflection on these problems, and on how personal actions can influence the community, and change (have an impact on) the probability of occurrence of a given event. 


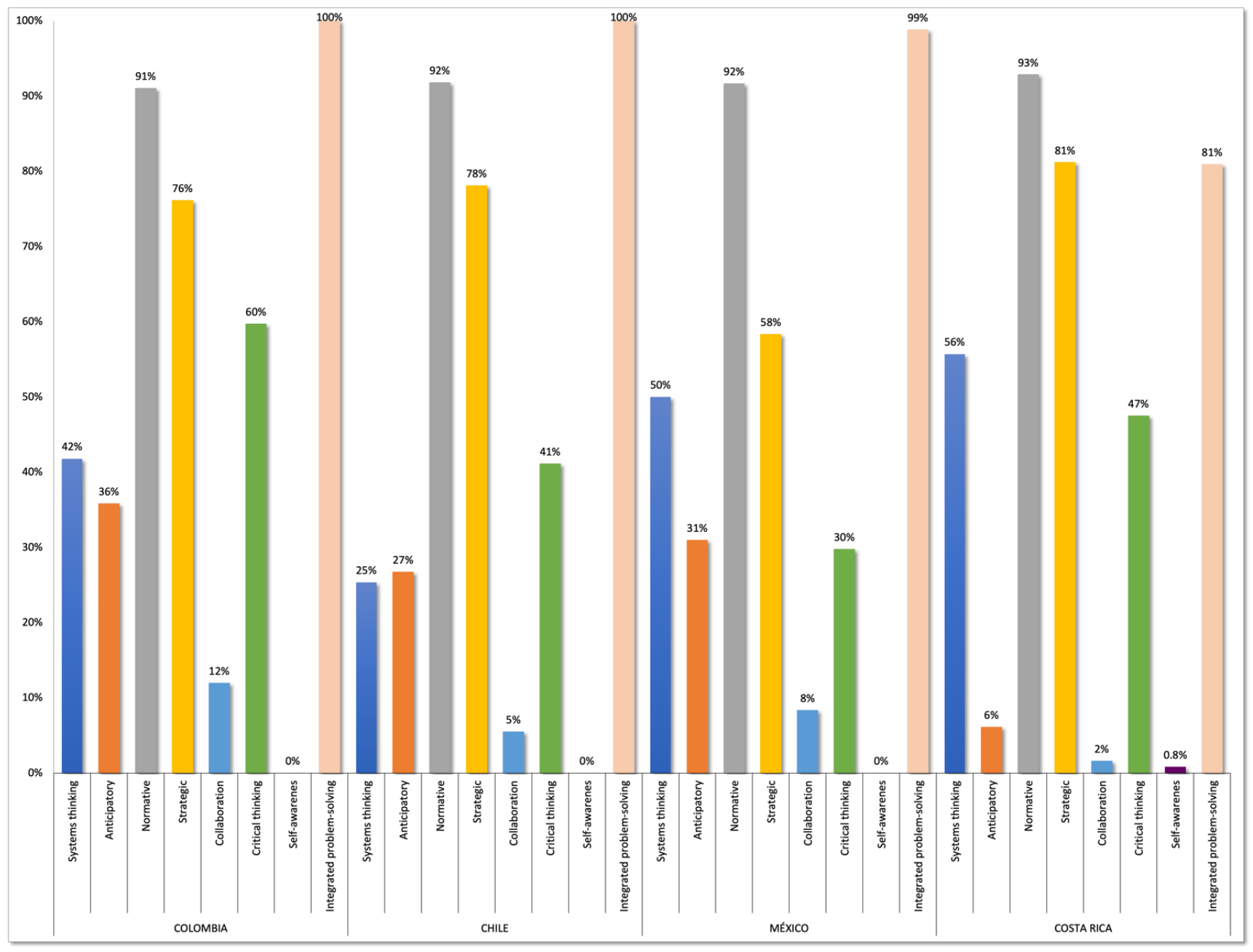

Figure 1. Competence distribution for sustainability by country.

If we analyze the results obtained in the curriculum documents by country, we observe that, in the case of Colombia, where 67 learning objectives proposed for the subject of mathematics were analyzed, all the learning objectives have the potential to promote problem-solving competence and, although to a lesser extent, also normative and strategic competences. Conversely, the skills of collaboration and anticipation are the least present.

In the Chilean curriculum, 146 learning objectives were analyzed. They identify the potential for developing mainly the same competences as in Colombia, while the competences with a lower percentage of allusion correspond to the competence of collaboration and systems thinking.

In the case of Mexico, the 84 learning objectives proposed in its curriculum documents that must be addressed in the subject of mathematics were analyzed. The results at the general level (Figure 1) show that such learning objectives have the potential to approximate the development of all problem-solving and anticipatory competences. In this case, the strategic competence has fewer learning objectives alluding to it than in the countries mentioned above.

Finally, in the case of the Costa Rican curriculum document, 377 learning objectives defined for the subject of mathematics were analyzed. At an overall level, there is evidence of the potential to trigger, to a greater extent, the key competences for normative, strategic, and problem-solving sustainability (Figure 1). Moreover, it is the only curriculum analyzed in which there are learning objectives with the potential to promote the competence of self-awareness, as mentioned above. It should be noted that in this country, compared to 
the three previous ones, the problem-solving competence is not the one with the highest number of related learning objectives.

Subsequently, we studied the competences in sustainability that promote the learning objectives of each country according to the mathematical axis to which they belonged: Numbers and operations, Geometry, Measurement, Algebra, and Statistics and Probability.

In the case of Colombia (Figure 2), none of the thematic axes refer to all the competences for sustainability. In other words, the thematic axes do not cover all the key competences for sustainability.

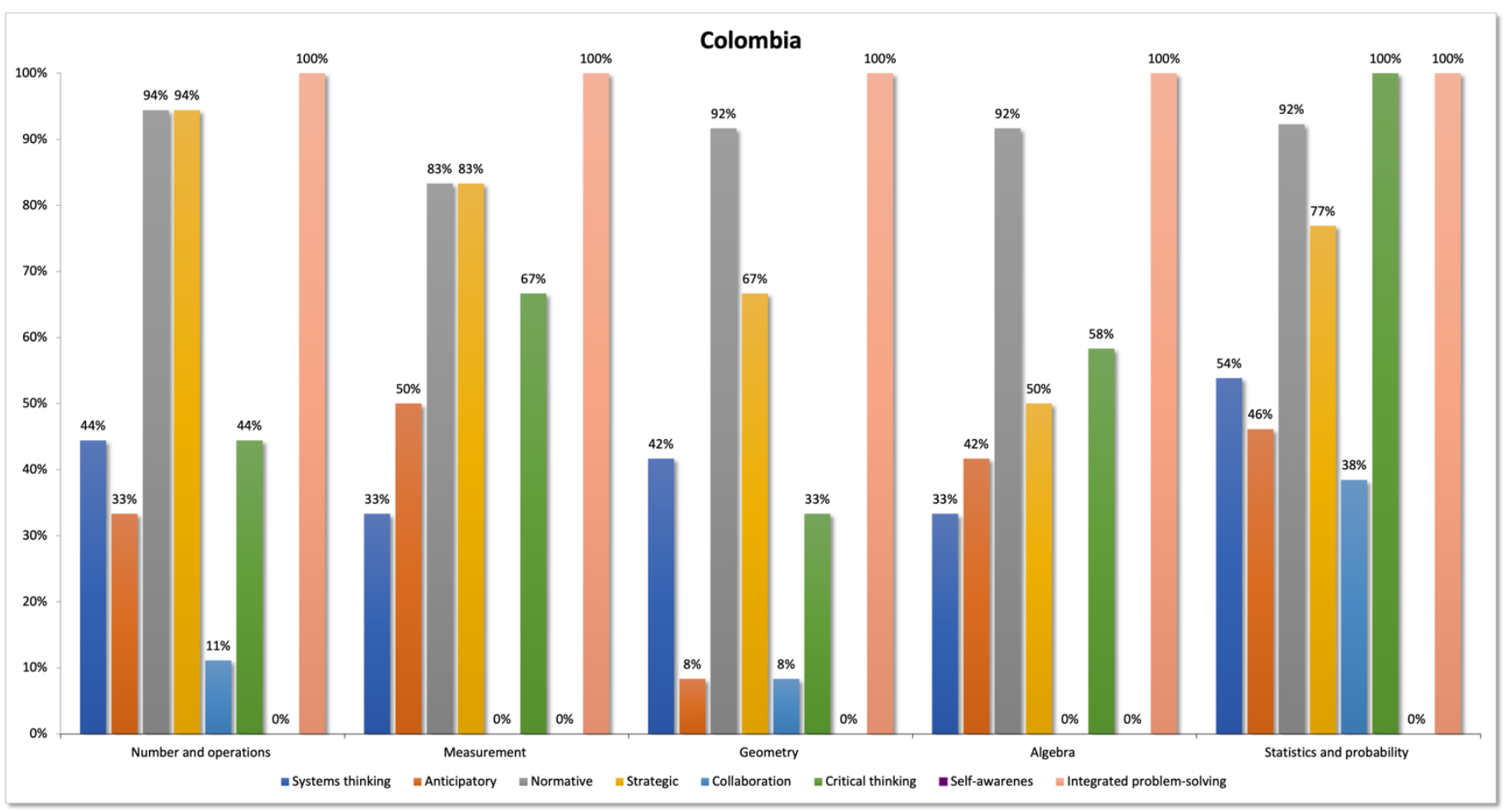

Figure 2. Sustainability competence distribution in Colombia according to thematic axis.

However, it is evident that the thematic axes of statistics and probability together with the axis of numbers and operations allude to seven of the eight key competences for sustainability. For example, let us look at the following learning objective associated with the statistics and probability axis set out for Grade 4 in the Colombian curriculum: "Collecting and organizing data in double-entry tables and representing them in grouped bar charts or line graphs to answer a given question. Interpreting information and communicating conclusions" [34] (p. 36). In this objective, there is a strong emphasis on the different stages of the statistical research cycle. This not only allows the development of systems thinking, if we link these research cycles to contexts that raise issues arising, for example, from the sustainable development goals, but can also trigger the development of other key competences for sustainability. Such is the case of normative competence, because from the interpretation of the information from the research cycle data, we can generate instances of reflection on norms and values; or strategic competence, if we use these reflections to activate the development of actions to implement sustainability, e.g., at school level.

On the other hand, the process of developing a statistical research cycle involves collaborative work, which requires skills to learn from others and facilitate collaborative problem solving (collaborative competence) in search of an answer to problems of various kinds, coming from different knowledge fields (problem solving competence). Finally, at the stage of interpretation and communication of information, critical thinking is necessary, leading to reflection on data, while understanding and evaluating multiple future scenarios (anticipatory competence). 
Similarly, in the following learning objective associated with the axis of numbers and operations proposed for Grade 1 in the Colombian curriculum: "Identifying the uses of numbers (as code, cardinal, measure, ordinal) and operations (addition and subtraction) in game contexts, family, economic, among others" [34] (p. 8); potential for the development of key competences is observed. In this objective, context plays an important role, and it is directly linked to several of the themes of the Sustainable Development Goals. Furthermore, it focuses on establishing relationships between the different uses of numbers and the operations of addition and subtraction, so this objective has the potential to generate learning instances that facilitate the development of systems, normative and strategic thinking, critical thinking, and problem-solving competences.

In the case of the Chilean curriculum and its potential to address the development of key competences for sustainability from the perspective of the thematic axes, it can be seen from Figure 3 that the statistics and probability axis also has the greatest potential. However, the competence of self-awareness is absent. In particular, we identified objectives that allow bridging the development of seven competences, only the competence of self-awareness does not appear. Furthermore, the competences of systems thinking and critical thinking can be developed from less than half of the learning objectives of this thematic axis.

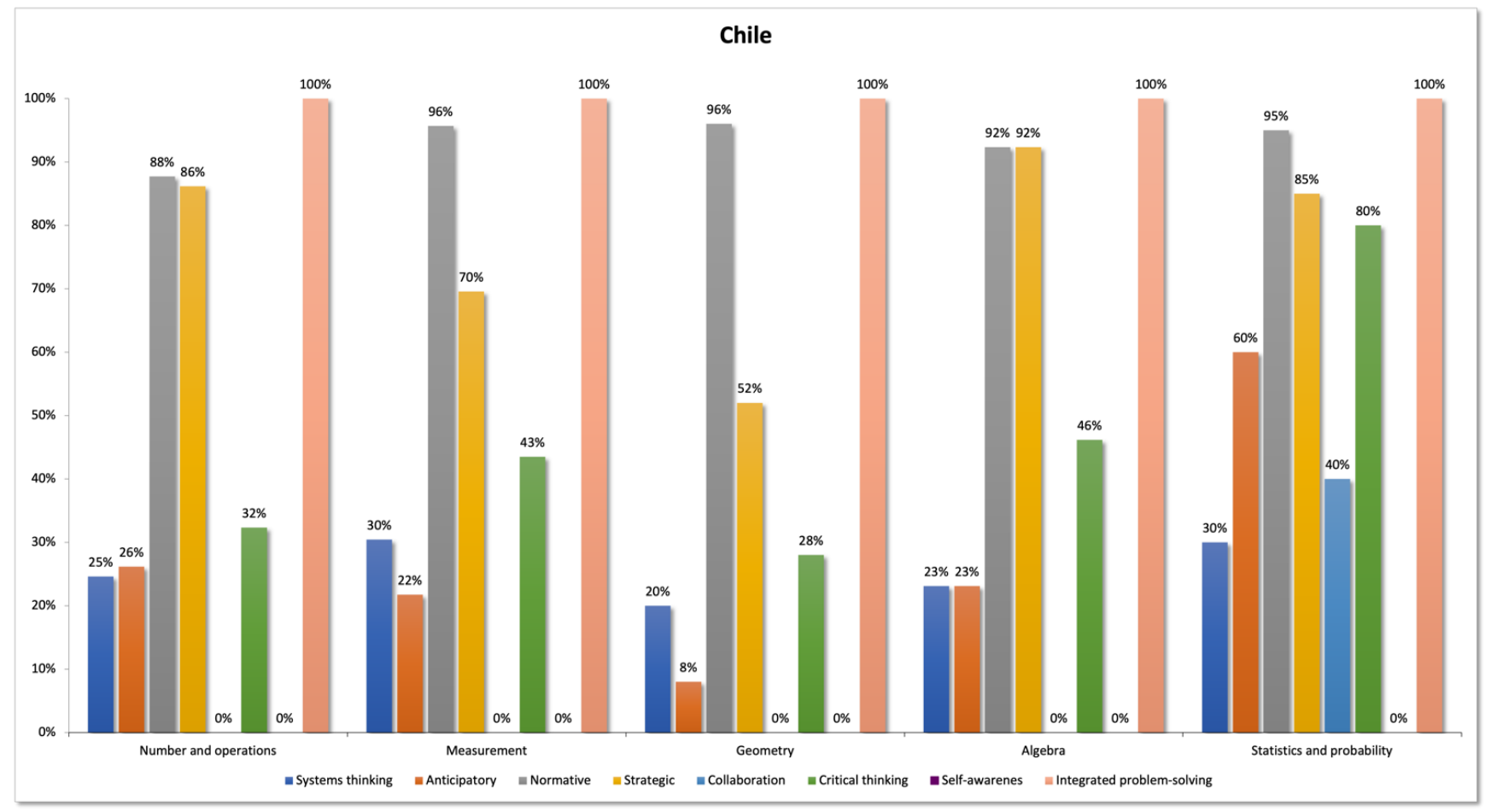

Figure 3. Sustainability competence distribution in Chile according to thematic axis.

Although the statistics and probability axis is the one that triggers the most competences, this does not mean that the other axes do not develop them, but rather that they are linked, but to a lesser extent. For example, in the case of the measurement axis, proximity is observed to favor the development of the key sustainability competences of systems thinking, anticipatory, normative, strategic, critical thinking, and problem solving. This is the case, for example, of the learning objective proposed for Grade 3: "Reading and interpreting timelines and calendars" [32] (p. 109). Here, we can observe proximity to the competences of systems thinking, normative, strategic, critical thinking, and problem solving. For example, if we approach the reading and interpretation of timelines related to different historical or social events that have occurred over time in a given country, beyond simple reading and interpretation, students could be encouraged to recognize and understand possible relationships that have led to such events (systems thinking), as well 
as the values, principles, and concessions that have led to the conflicts to which such events could be linked (normative competence).

In the case of the Mexican curriculum, with regards to the potential of the learning objectives linked to the thematic axes, it is observed, firstly, that, as was the case in the curricula of the previous countries, none of the thematic axes comes close to the totality of the competences for sustainability (Figure 4). Once again, the statistics and probability axis is the one with the strongest link to sustainability competences; specifically, it shows the potential for favoring the development of all the competences, except self-awareness. All of them have a percentage of over $50 \%$.

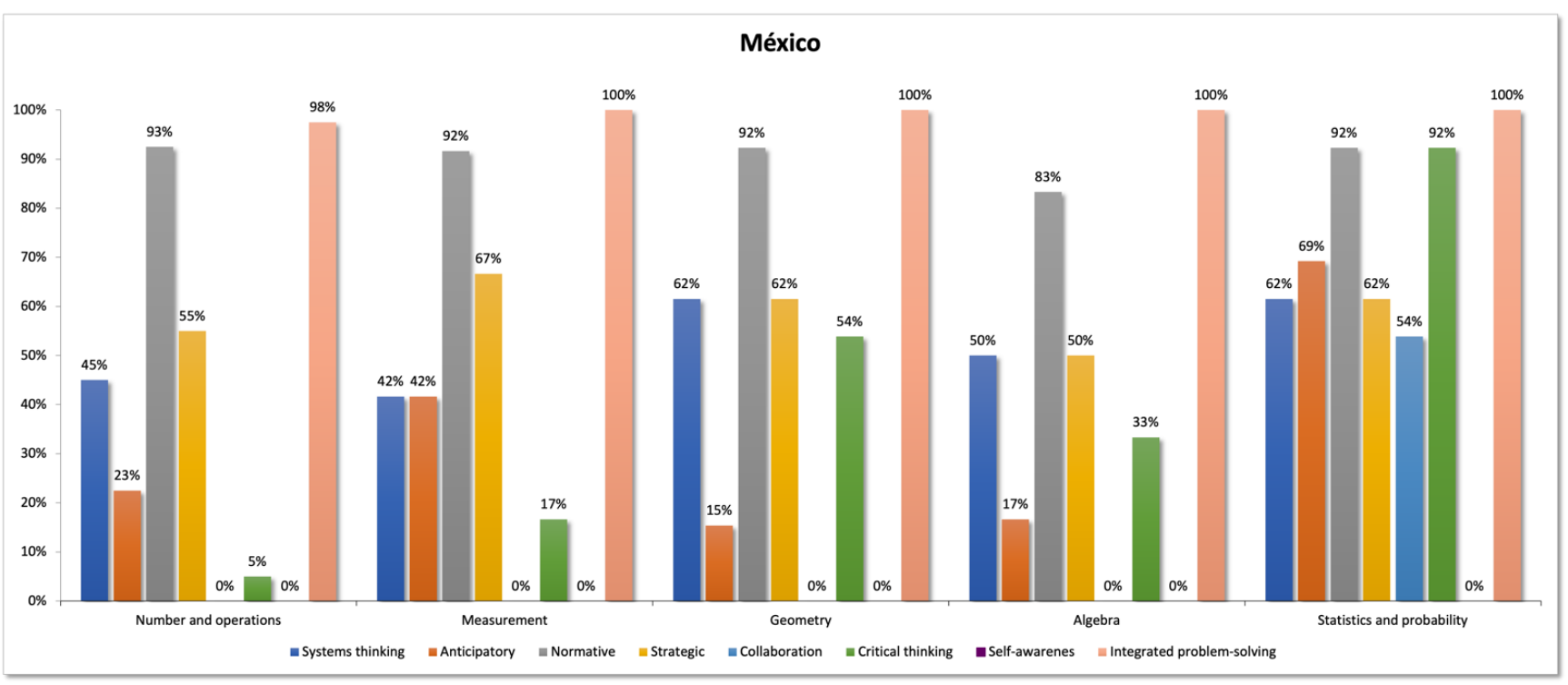

Figure 4. Sustainability competence distribution in Mexico according to thematic axis.

The thematic axes that present fewer opportunities to link with key competences are the algebra axis and the measurement axis. As an example, we find the following learning objective linked to the thematic axis of algebra proposed for grade 6: "solving percentage calculating problems and percent" [31] (p. 321). Such an objective can be approached from diverse contexts that are related to topics from the SDGs, allowing not only to build bridges with the problem-solving competence, but also with the strategic and critical thinking competence. Thus, based on these competences, students can reflect on the percentages in the context involved and propose innovative actions that promote sustainability. In this way, they would be able to recognize and understand the relationships between different types of systems (systems thinking) in which these percentages may be involved, according to the SDG selected. Similarly, from this objective, students can be led towards the development of normative competence.

Regarding the analysis of the Costa Rican curriculum, it can be seen from Figure 5 that it is also the statistics and probability axis that shows the greatest ease in triggering competences for sustainability. Specifically, in view of the learning objectives that make up this thematic axis, the possibility of triggering the development of some of the seven competences for sustainability is evident. In this case, the absent competence is anticipation, and, except for collaboration and self-confidence, the other competences present have a percentage of objectives that allude to them above $70 \%$. An example of this can be seen in the following learning objective proposed for Grade 3: "interpreting concepts of most probable, equally probable or less probable events" [35] (p. 159). This objective has the potential to approach the development of the following competences: systems thinking, normative, strategic, critical thinking, and problem solving. One way of doing this could be to select a context from the different topics addressed by the SDGs, for example, food and the likelihood of developing certain diseases. By working on the probability concepts 
outlined above, students can think and rethink about the integration of different systems and deal with uncertainty (systems thinking), reflect on how the norms and values that underlie our actions can influence them (normative), and design and implement actions that promote sustainability (strategic). This certainly requires critical thinking, which allows them to question their practices and opinions, to solve and put into practice the problematic situation posed.

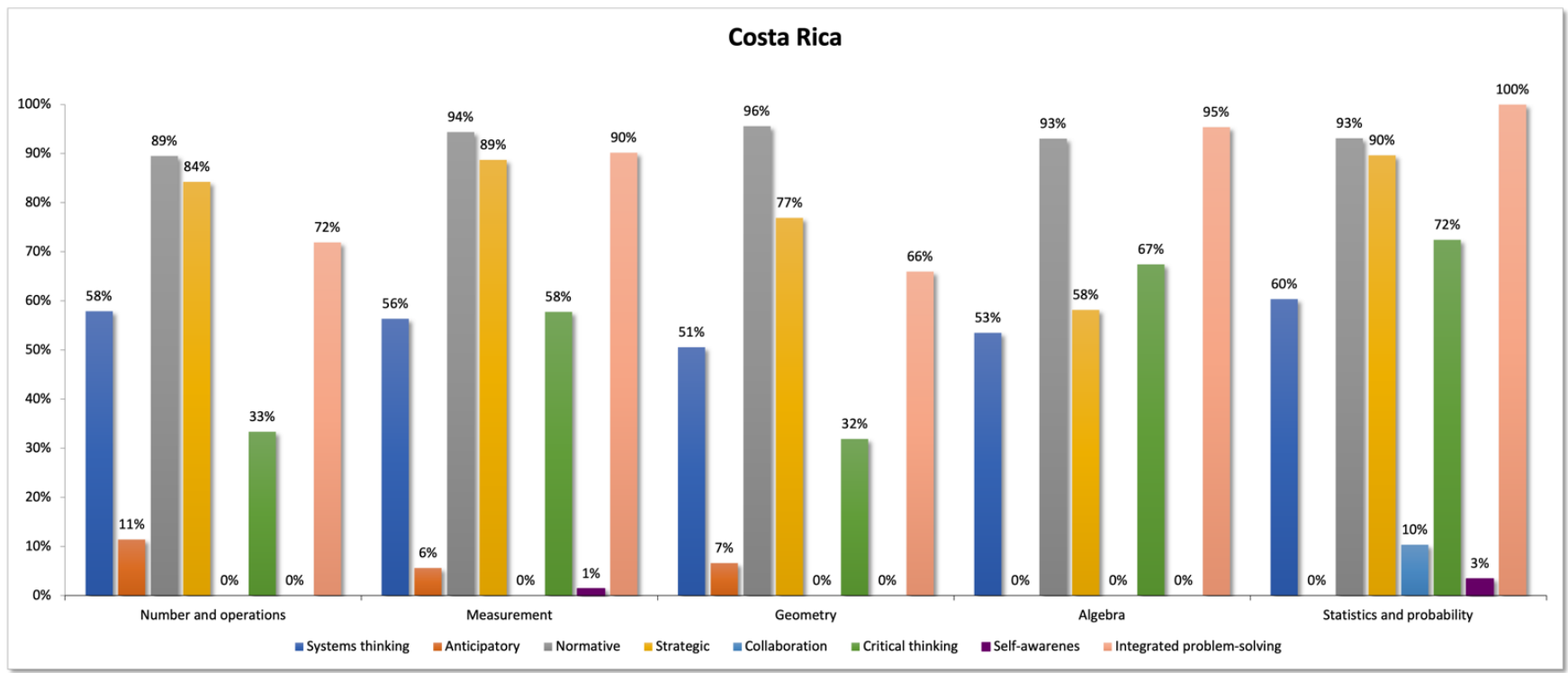

Figure 5. Sustainability competence distribution in Costa Rica according to thematic axis.

On the other hand, it is important to note that the other thematic axes also have potential for the development of key sustainability competences, but to a lesser extent.

\section{Discussion and Final Considerations}

The results on the presence of approaches and key competences promoting ESD in the mathematics curriculum allow for a discussion in which teachers' knowledge would be challenged. In particular, the results show that the contextual approach is the one most present in the curriculum documents. This approach "gives relevance to local culture as a source of inspiration for change for sustainability [...]. And, hence, ESD must place the emphasis on providing people with the capacities they most need in each case for the transition of their local context towards sustainability" [39] (p. 64).

In a mathematics classroom, therefore, this would mean using local contexts related to developing ESD in which mathematics plays a role. This fact makes it necessary for mathematics teachers to be clear about the "phenomenology and applications" [8] (p. 244) of mathematical concepts. This would allow tasks proposed in the classroom to provide opportunities to learn the mathematical concept in local contexts that promote ESD.

Concerning the second most common approach, the critical approach, this "requires competences for awareness, intellectual competences and ethical competences" [39] (p. 64). Consequently, it requires teachers to have knowledge of the development of critical thinking in mathematics education, i.e., knowledge of features of learning mathematics (KFLM) in terms of the MTSK. In particular, it requires knowledge of mathematics learning theories and emotional aspects of mathematics learning [8]. Likewise, the critical approach requires that critical thinking questions "the dominant paradigm, its production-consumption model and associated lifestyles, from which large crowds are excluded" [39] (p. 64). Therefore, it is necessary for the mathematics teacher to also hold knowledge about "how mathematics can be used in the classroom to address linked issues in the social-ecological system that is the human life support system" [40] (p. 34). That is, they require knowledge 
of the phenomenology and applications of mathematical concepts, as mentioned in the previous paragraph.

In relation to the integrative approach, it emphasizes a holistic perspective, and thus, places emphasis on "people being able to use a relational and, at the same time, integrative type of thinking" [39] (p. 64). This implies, among others, "knowledge of the structure of mathematics" (KSM) [8] (p. 245). This domain implies knowing about the inter-conceptual connections of mathematical ideas; therefore, the teacher should aim for students to understand school mathematics as a complex network that is related to each other.

Finally, the transformative approach implies certain behaviors that are consistent with ESD. Specifically, it "implies a step further than that [critical approach] after awarenessraising, consequent change towards socially, economically, and ecologically sustainable lifestyles" [39] (p. 64). Therefore, it challenges the mathematics teacher in their knowledge about teaching mathematics and specifically about designing learning opportunities that provide scenarios for students to become aware and to move towards acting in a consequently sustainable way.

Contextual and critical approaches are present to a large extent in the analyzed curricula. Therefore, it is plausible to think that the knowledge described above should be made explicit in terms of its link to sustainability so that teachers can become aware of this and be effective in bringing ESD into the mathematics classroom. However, the fact that integrative and transformative approaches are less present might make them go unnoticed. Hence, it not only challenges teachers' knowledge of the discipline and didactic knowledge, but also invites them to be aware of and promote such knowledge to foster ESD.

On their behalf, the results of the key competences indicate that, in all the curricular documents analyzed, the integrated problem-solving, normative, and strategic competences are the most present. The integrated problem-solving key competence is understood as the ability "to apply different problem-solving frameworks to complex sustainability problems and develop viable, inclusive and equitable solution options that promote sustainable development, integrating the abovementioned competences" [1] (p. 10), which requires from teachers both knowledge of practices in mathematics (KPM) and knowledge of mathematics teaching (KMT). The former will be necessary to be able to provide problemsolving opportunities across different settings. As pointed out in [8], the named subdomain concerns "not only to the teacher's awareness of mathematical reasoning (in general and with respect to specific topics); KPM is also about knowing how to explore and generate new knowledge in mathematics" [8] (p. 246). The second subdomain noted (KMT) will be necessary as it is "knowledge of different ways of representing specific content (whether through metaphors, situations or explanations)" [8] (p. 248), i.e., designing learning opportunities that have complex sustainable contexts and in which students can offer sustainable solutions.

Normative competence is described as "to understand and reflect on the norms and values that underlie one's actions; and to negotiate sustainability values, principles, goals, and targets, in a context of conflicts of interests and trade-offs, uncertain knowledge and contradictions" [1] (p. 10). This means the need to sustain knowledge of topics (KoT) and knowledge of practices in mathematics (KPM). Regarding the former, it is necessary because a central aspect of this subdomain is related to how and when one does something or why something is done in a certain way [8]. Therefore, it would allow mathematics teachers to develop their students' reflective processes in which they can analyze rules and properties underlying the mathematical concepts they are learning. Moreover, when being in contexts of sustainability, it is necessary to know the phenomenology and applications of the concepts in order for ESD to emerge. Likewise, the knowledge of practices, which allows knowing how to explore and generate new knowledge, would be the teacher's task to be able to evaluate the contexts in terms of the development of sustainability.

Strategic competence is described as "to collectively develop and implement innovative actions that further sustainability at the local level and further afield" [1] (p. 10). 
Therefore, it directly concerns didactic content knowledge, particularly knowledge of mathematics teaching (KMT). This is because the latter is related to the strategies that the teacher will use [8], which in this case makes it necessary to promote collective work in the classroom in favor of sustainability.

Critical thinking competence, systems thinking, and anticipation are present to a lesser extent in the curriculum documents. The key competence of critical thinking refers to being able "to question norms, practices and opinions; to reflect on one's own values, perceptions and actions; and to take a position in the sustainability discourse" [1] (p. 10). The systems thinking competence refers to being able "to recognize and understand relationships; to analyse complex systems; to think of how systems are embedded within different domains and different scales; and to deal with uncertainty" [1] (p. 10). Anticipatory competence which is described as "to understand and evaluate multiple futures-possible, probable and desirable; to create one's own visions for the future; to apply the precautionary principle; to assess the consequences of actions; and to deal with risks and changes" [1] (p. 10). Therefore, for critical thinking and anticipatory competences, mathematics teachers will need to mobilize their knowledge of practices in mathematics (KPM). In the case of the critical thinking competence, it allows to manage students' mathematical reasoning, accepting, refuting, or refining theories if necessary [8]. Anticipatory competence, the assessment of possible outcomes, application, and evaluation of situations in which we do not know the outcome, is strongly related to a mathematical problem and the process of problem solving [20]. Consequently, mathematics teachers will need to mobilize their knowledge of the structure of mathematics (KSM), as they will need to be clear about interconceptual or auxiliary connections and cross-conceptual connections to develop students' ability to think complex systems [8]. However, these actions need to be linked to local contexts that promote sustainability and, therefore, ESD.

The key competences of collaboration and self-awareness are the least present in the curriculum documents. The collaborative competence is described as "to learn from others; to understand and respect the needs, perspectives and actions of others (empathy); to understand, relate to and be sensitive to others (empathic leadership); to deal with conflicts in a group; and to facilitate collaborative and participatory problem solving" [1] (p. 10). Thus, it challenges mathematics teachers' knowledge related to features of learning mathematics (KFLM) and specifically, the emotional aspects of learning mathematics. This is because the teacher must possess knowledge about how non-cognitive aspects affect mathematics learning, both at the individual student and the whole group level, and their interactions.

Finally, the competence of self-awareness is described as "to reflect on one's own role in the local community and (global) society; to continually evaluate and further motivate one's actions; and to deal with one's feelings and desires" [1] (p. 10). In this sense, it is necessary for the mathematics teacher to have knowledge about features of learning mathematics (KFLM) and specifically knowledge about the theories of mathematical learning that allows them to understand how to connect these aspects with individual and collective reflection processes that motivate ESD.

The key competences for sustainability that have had the least presence in curriculum documents are the competences of anticipation, collaboration, and self-awareness. This highlights the need for mathematics teachers to be alert to incorporate them into their classroom strategy when thinking about developing ESD-focused teaching in the mathematics classroom.

Throughout this study, the curricula of four Latin American countries have been analyzed with a twofold objective: to analyze the approach to sustainability teaching that dominates and the potential of the learning objectives to develop key competences in sustainability. As a direct consequence of the results of these two studies, and using the MTSK teacher knowledge model, we have been able to describe the teacher's knowledge necessary to be able to orient their teaching towards ESD, based on the curricula studied. 
Overall, we have observed that the results obtained in the four curricula were very similar, which means that the curricula are not oriented towards the full development of ESD.

From the first objective, related to the approaches to ESD in the curricula analyzed, we observe that, although all the approaches can be extracted from the curricula analyzed, the contextual approach has been the predominant one. This is consistent with curricula that are situated in their setting and aim to develop knowledge anchored in the contextualization of mathematics. Next, it is striking that the transformative approach is in the minority in three of the countries studied, except for Chile, where the integrative approach is in the minority. In the development of ESD, it seems necessary to move towards a more pragmatic vision that seeks the real transformation of lifestyles, towards sustainability literacy [14]. Although in Chile this pragmatic vision exists, the holistic approach, which offers a reality with its connected elements, is not encouraged. From the perspective of teacher knowledge, we observe that it is necessary for teachers to incorporate knowledge of mathematical structure (KSM) and the characteristics of learning (KFLM), which will enable them to develop approaches that are less present in the curriculum. Since if ESD is to be promoted, and because they are not predominant approaches in curricula, this knowledge must be incorporated into initial or in-service teacher training [11]. Only in this way will teachers be able to promote these approaches. This is consistent with other research that highlights the need to develop specific ESD training for teachers [4].

From the analysis of the key competences in sustainability and their allusion in the learning objectives present in the curricula studied, we have been able to observe that the content axes of statistics and probability, as well as numbers and operations, are those with the greatest number of objectives related to the key competences for sustainability. At the other extreme are the other axes, with similar behavior among the different curricula studied. This points to the fact that, once again, it is up to the teacher and their ability to connect with the key competences of sustainability, when the curriculum does not facilitate it. The key competence of self-awareness stands out for its absence or very low presence. This is significant because the curricula make no reference to aspects related to the responsibility of the decisions that future citizens make about our setting. This is of relevance in sustainability training. In addition, there are two competences with a low presence, namely collaborative and normative competences. This gap that appears with these competences must be filled by training the teacher in the knowledge related to them, according to the MTSK model: of the characteristics of learning mathematics (KFLM), mathematical structure (KSM), and mathematical practice (KPM).

The study presented here has explored the knowledge of teachers and the competences required for the development of SDGs in the classroom [13]. On the one hand, it provides information about the axes of mathematical content that facilitates the promotion of key competences in sustainability. This will help in the construction of future mathematical activities aimed at building sustainability-competent citizens. On the other hand, it determines a training framework for future teachers, focusing on the knowledge that, according to the MTSK model, is necessary for the development of ESD in the classroom. The university must be the center for the development of citizens who will lead the planet in the future, and, in the case of future teachers, the responsibility is even greater, as they must have the capacity to promote and consolidate the key competences in sustainability of the rest of the citizens.

ESD is fundamental to ensure citizens are committed to the SDGs in the 21st century. Teachers and trainers of future teachers are primarily responsible for this, as each of us in our own area of action must manage to train teachers with the capacity for social change and competent citizens in sustainability.

Author Contributions: All authors contributed equally to conceptualization, formal analysis, investigation, methodology, project administration, writing — original draft and writing - review \& editin. All authors have read and agreed to the published version of the manuscript. 
Funding: Work was carried out within the framework of the FONDECYT project No. 1200356 financed by the National Research and Development Agency (ANID) of the Government of Chile.

Institutional Review Board Statement: Not applicable.

Informed Consent Statement: Not applicable.

Conflicts of Interest: The authors declare no conflict of interest.

\section{References}

1. UNESCO. Education for Sustainable Development Goals: Learning Objectives; UNESCO: Paris, France, 2017. Available online: https://unesdoc.unesco.org/ark:/48223/pf0000247444 (accessed on 2 June 2020).

2. Cebrián, G.; Junyent, M.; Mulà, I. Current Practices and Future Pathways towards Competencies in Education for Sustainable Development. Sustainability 2021, 13, 8733. [CrossRef]

3. Cebrián, G.; Junyent, M. Competencies in Education for Sustainable Development: Exploring the Student Teachers' Views. Sustainability 2015, 7, 2768-2786. Available online: http://www.mdpi.com/2071-1050/7/3/2768 (accessed on 2 June 2020). [CrossRef]

4. Vásquez, C.; García-Alonso, I. La educación estadística para el Desarrollo Sostenible en la Formación del Profesorado. Curric. Form. Profr. 2020, 24, 125-147.

5. Ball, D.L.; Lubienski, S.T.; Mewborn, D.S. Research on Teaching Mathematics: The Unsolved Problem of Teachers' Mathematical Knowledge. In Handbook of Research on Teaching, 4th ed.; Richardson, V., Ed.; AERA: Washington, DC, USA, 2001 ; pp. $433-456$.

6. Hill, H.C.; Rowan, B.; Ball, D.L. Effects of Teachers' Mathematical Knowledge for Teaching on Student Achievement. Am. Educ. Res. J. 2005, 42, 371-406. [CrossRef]

7. Kilpatrick, J. Más Rico: Una historia actualizada de investigación en Educación Matemática. In Investigaciones en Educación Matemática; Rico, H.A.L., Castro, E., Castro, E., Lupiáñez, J.L., Ruíz-Hidalgo, J.F., Torralbo, M., Eds.; Comares: Granada, Spain, 2016; pp. 33-44.

8. Carrillo-Yañez, J.; Climent, N.; Montes, M.; Contreras, L.C.; Flores-Medrano, E.; Escudero-Ávila, D.; Vasco, D.; Rojas, N.; Flores, P.; Aguilar-González, Á.; et al. The mathematics teacher's specialised knowledge (MTSK) model. Res. Math. Educ. 2018, 20, 236-253. [CrossRef]

9. Vásquez, C.; Seckel, M.J.; Alsina, A. Belief system of future teachers on Education for Sustainable Development in math classes. Uniciencia 2020, 34, 1-30. [CrossRef]

10. UNESCO. Transforming Our World: The 2030 Agenda for Sustainable Development; UNESCO: Paris, France, 2015. Available online: https://www.un.org/ga/search/view_doc.asp?symbol=A/RES/70/1\&Lang=E (accessed on 2 June 2020).

11. Ball, D.L.; Hill, H.C.; Bass, Y.H. Knowing mathematics for teaching: Who knows mathematics well enough to teach third grade, and how can we decide? Am. Ed. 2005, 29, 14-17, 20-22, 43-46.

12. Deng, Z. Pedagogical content knowledge reconceived: Bringing curriculum thinking into the conversation on teachers' content knowledge. Teach. Teach. Educ. 2018, 72, 155-164. [CrossRef]

13. Schweizer, C.R.; Di Giulio, A.; Burkhardt-Holm, P. Scientific Support for Redesigning a Higher-Education Curriculum on Sustainability. Sustainability 2019, 11, 6035. [CrossRef]

14. Stibbe, A. (Ed.) The Handbook of Sustainability Literacy: Skills for a Changing World; Green Books: Devon, UK, 2009.

15. Rychen, D.S. Competencias clave: Abordar desafíos importantes en vida. In Competencias Clave Para Una Vida Exitosa y Una Sociedad Sana; Rychen, D.S., Salganik, L.H., Eds.; Hogrefe y Huber: Cambridge, MA, USA, 2003; pp. 63-107.

16. Weinert, F. Concept of Competence: A Conceptual clarification. In Definition and Selection Key Competencies; Rychen, D., Salganik, L., Eds.; Hogrefe and Huber: Gottingen, Germany, 2001; pp. 45-65.

17. Wals, A.E.J. Más Allá de Dudas no Razonables. Educación y Aprendizaje Para la Sostenibilidad Socioecológica en el antropoceno; Universidad de Wageningen: Wageningen, The Netherlands, 2015.

18. Alsina, Á. Itinerarios Didácticos Para la Enseñanza de Las Matemáticas (6-12 años); Editorial Graó: Barcelona, Spain, 2019.

19. OECD. Pisa 2006 Science Competencies for Tomorrow's World; OECD: París, France, 2007. Available online: https://www.oecdilibrary.org/education/pisa-2006_9789264040014-en (accessed on 28 July 2021).

20. Piñeiro, J.L. Conocimiento Profesional de Maestros en Formación Inicial Sobre la Resolución de Problemas en Matemáticas. Ph.D Thesis, Universidad de Granada, Granada, Spain, 2019.

21. Shulman, L.S. Those Who Understand: Knowledge Growth in Teaching. Ed. Res. 1986, 15, 4-14. [CrossRef]

22. Leicht, A.; Heiss, J.; Byun, W.J. Issues and Trends in Education for Sustainable Development; UNESCO: Paris, France, 2018.

23. UNESCO. Shaping the Education of Tomorrow: 2012 Report on the UN Decade of Education for Sustainable Development, Abridged; UNESCO: Paris, France, 2012.

24. Uitto, A.; Saloranta, S. Subject Teachers as Educators for Sustainability: A Survey Study. Educ. Sci. 2017, 7, 8. [CrossRef]

25. Dahl, T. Prepared to Teach for Sustainable Development? Student Teachers' Beliefs in Their Ability to Teach for Sustainable Development. Sustainability 2019, 11, 1993. [CrossRef]

26. UNESCO. Progress on Education for Sustainable Development and Global Citizenship Education; UNESCO: Paris, France, 2018. Available online: https:/ / unesdoc.unesco.org/ark:/48223/pf0000266176 (accessed on 2 June 2020). 
27. Minguet, P.A.; Martínez-Agut, M.P.; Palacios, B.; Piñero, A.; Ull, M.A. Introducing sustainability into university curricula: An indicator and baseline survey of the views of university teachers at the University of Valencia. Environ. Educ. Res. 2011, 17, 145-166. [CrossRef]

28. Hernández, R.; Fernández, C.; Baptista, P. Metodología de la Investigación, 6th ed.; McGraw-Hill Education: Mexico City, México, 2014.

29. Rico, L.Y.; Fernández-Cano, A. Análisis Didáctico y Metodología de Investigación. In Análisis Didáctico en Educación Matemática. Metodología de Investigación, Formación de Profesores e Innovación Curricular; Rico, L., Lupiáñez, J.L., Molina, M., Eds.; Comares: Granada, Spain, 2013; pp. 1-22.

30. OECD. OECD Welcomes Costa Rica as its 38th Member [Newsletter]. Available online: https://www.oecd.org/newsroom/oecdwelcomes-costa-rica-as-its-38th-member.html (accessed on 28 July 2021).

31. Secretaría de Educación Pública. Aprendizajes Clave para la Educación Integral. Plan y Programas de Estudio para la Educación Básica. 2017. Available online: https:/ / www.planyprogramasdestudio.sep.gob.mx/descargables/APRENDIZAJES_CLAVE_ PARA_LA_EDUCACION_INTEGRAL.pdf (accessed on 28 July 2021).

32. Ministerio de Educación. Bases Curriculares Educación Básica. Unidad Curriculum y Evaluación. 2012. Available online: https://www.planyprogramasdestudio.sep.gob.mx/descargables/APRENDIZAJES_CLAVE_PARA_LA_EDUCACION_ INTEGRAL.pdf (accessed on 28 July 2021).

33. Ministerio de Educación Nacional. Estándares Básicos de Competencias en Lenguaje, Matemáticas, Ciencias y Ciudadanas. Guía Sobre lo que los Estudiantes Deben Saber y Saber hacer con lo que Aprenden. 2006. Available online: https://www. planyprogramasdestudio.sep.gob.mx/descargables/APRENDIZAJES_CLAVE_PARA_LA_EDUCACION_INTEGRAL.pdf (accessed on 28 July 2021).

34. Ministerio de Educación Nacional. Derechos Básicos de Aprendizaje. Matemáticas. 2017. Available online: https://www. planyprogramasdestudio.sep.gob.mx/descargables/APRENDIZAJES_CLAVE_PARA_LA_EDUCACION_INTEGRAL.pdf (accessed on 28 July 2021).

35. Ministerio de Educación Pública. Programa de Estudio de Matemáticas. 2012. Available online: https:/ / www.planyprogramasdestudio. sep.gob.mx/descargables/APRENDIZAJES_CLAVE_PARA_LA_EDUCACION_INTEGRAL.pdf (accessed on 28 July 2021).

36. Krippendorff, K. Content Analysis: An Introduction to Its Methodology, 3rd ed.; Sage Publications: Los Angeles, CA, USA, 2013.

37. Bardin, L. Análisis de Contenido, 2nd ed.; Akal: Madrid, Spain, 1996.

38. Kuckartz, U. Qualitative text analysis: A systematic approach. In Compendium for Early Career Researchers in Mathematics Education; Kaiser, G., Presmeg, N., Eds.; Springer: Cham, Switzerland, 2019; pp. 181-198.

39. Murga-Menoyo, M. Ángeles Competencias para el desarrollo sostenible: Las capacidades, actitudes y valores meta de la educación en el marco de la Agenda global post-2015. Foro Educ. 2015, 13, 55-83. [CrossRef]

40. Hamilton, J.; Pfaff, T.J. Social Justice and Sustainability: Two Perspectives on the Same System. In Mathematics for Social Justice: Resources for the College Classroom; Karaali, G., Khadjavi, L.S., Eds.; MAA Press: Providence, RI, USA, 2019 ; pp. 32-33. 